\title{
Practices of Internal Marketing in Small and Medium Industry
}

\author{
Zarina Abd Munir, Akmal Aini Othman, Shamsul Azren Mohd Shukur, Rahimah Ithnin, and Syezreen \\ Dalina Rusdi
}

\begin{abstract}
This study is conducted in order to examine the adoption of internal marketing activities in small and medium enterprises in Malaysia. On top of that, this particular study is designed in order to investigate the conception of internal marketing by business manager's task adding to the limited empirical evidence regarding internal marketing especially in a developing country like Malaysia. Base on previous literature and few in depth interviews with the SME's managers, a set of questionnaires related to internal marketing practices in SME's Industry has been designed. Few dimensions have been used in this study such as group interaction, wage flexibility, collegial interaction, job flexibility, external environment and formal interaction. Basically the result of the study will give some input to those governmental agencies such as MECD to understand the level of adoption of internal marketing activities among the SMEs in Malaysia particularly. With this, it will provide some direction to the agencies in designing and developing appropriate training related to managerial approach especially in term of the soft part of human resource practices that would lead to competitive advantage to the organization.
\end{abstract}

Index Terms-Internal marketing, SME industry, marketing.

\section{INTRODUCTION}

Internal Marketing (IM) is a new and emerging discipline that has been practiced in many big organizations particularly, under different names. Some might refer it as internal marketing while others might call it as employee engagement or internal communication. Nevertheless the concept is the same: to align, motivate and empower employees at all functions and levels- to consistently deliver positive customer experiences that are aligned with the firm's organizational goals. This definition of internal marketing advances the notion that the discipline is more than communication tactics -such as workplace posters and employee meetings- or a way to build employee satisfaction. Instead, it recognizes that IM can be deployed as a strategic tool to help an organization achieve its business objectives. This study is conducted in order to examine the use of internal marketing activities in small and medium enterprises in Malaysia.

Manuscript received January 2, 2014; revised March 7, 2014.

Zarina Abd Munir, Akmal Aini Othman, Shamsul Azren Mohd Shukur, and Syezreen Dalina Rusdi are with the Faculty of Business Management, University Teknologi MARA, Malaysia (e-mail: zarin453@salam.uitm.edu.my).

Rahimah Ithnin is with the Ministry of Communication and Multimedia Malaysia.

\section{LITERATURE REVIEW}

"A direct link between human capital and corporate financial results is not readily apparent in traditional accounting practices. Right now, we are only beginning to understand the potential of this tool, but it's the measurement process that's important... Once we are able to measure intangible assets more accurately, I think investors and finance professionals will begin to look at human capital metrics as another indicator of a company's value."

\section{Lawrence $R$ Whitman, GTE Corporation}

According to the statement, Whitman has predicted that the new era of strategy will need organizations to look in depth on the extension of the marketing strategy which is the Internal Marketing. According to [1], defined Internal Marketing asa planned effort using a marketing-like approach to overcome organizational resistance to change and to align, motivate and inter-functionally co-ordinate and integrate employees towards the effective implementation of corporate and functional strategies in order to deliver customer satisfaction through a process of creating motivated and customer-orientated employees.

Researchers have also identified some issues related to IM include: the link between employee satisfaction and organizational performance; the need for research on how inter-functional co-ordination can be achieved for the effective implementation of marketing strategies; the need for relationship marketing perspective in internal marketing; the need for research in internal communication strategies; and the role of internal marketing for developing organizational competences [2]. Furthermore, the basic purpose for applying internal marketing concept is to get motivated employees and to make them conscious at each and every level to serve customer in a better way [3], [4]

According to [5] has come out with three reasons why we need to conduct employee research:

1) Employees themselves are customer of internal service

2) Employees offer insights into the condition that effects service quality in an organization as they experience the service delivery system on a daily basis.

3) As an early warning system to marketers, as employees are able to identify when the system is going to break down

In Malaysia, internal marketing is still a new strategy for most of the organization although informally there are organizations practicing it but not in depth. Due to this, researchers would like to investigate the use on the internal marketing in the small and medium Enterprises. The research will be concentrated towards the understanding of the 
managers on Internal Marketing. [6] have suggested that managers should be the one that initiate internal marketing in organizations.

Many proponents of Internal Marketing follow [7] original view point, firstly by emphasising its relevance to service firms in particular; and in general, by seeing the employee as an internal customer [7], who is an important party in delivering satisfaction to ex ternal customers, and whose support of overall marketing strategy is essential if this is to succeed [8].

Internal marketing may be able to improve the degree to which members of the organization are linked by interpersonal networks (interconnectedness), thus increasing the flow of new ideas. It can develop, encourage and support internal change agents with appropriate marketing skills, to operate in an internal market. An initial descriptive study on the practices of IM among the SMEs particularly, may provide a momentum towards better understanding of the concept and hence will lead to further comprehensive study in the future. Thus will help to generate greater input to parties, the practitioners and the academia.

\section{Methodology}

\section{A. Population/Respondents}

The population for this research is small and medium enterprises that listed in small and medium industries development corporation (SMIDEC). We randomly selected respondents from the population as our sample. We choose 250 entrepreneurs that being awarded by SMIDEC. The selected companies are from various types of industries.

\section{B. Procedure}

A set of questionnaire was constructed in collecting the data. Several dimensions have been used in this study such as group interaction, wage flexibility, collegial interaction, job flexibility, external environment and formal interaction. Those questionnaires were mailed to the selected entrepreneur or owners and they are given ten days to complete and return it to us. From 250 questionnaires that had been distributed, 66 entrepreneurs or owners returned it. The data collection has been analyzed through descriptive analysis and frequencies analysis.

\section{FINDING AND ANALYSIS}

\section{A. Measure Validation}

The measure of validation was evaluated by conducting confirmatory factor analysis. This is due to the questionnaire that been used was taken from previous study that has been validated. To confirm this Cronbach alpha coefficients test were conducted. The result reported that all factors loading are higher than 0.60 .Highest score is 0.78 for the "collegial interaction" while the lowest is for is 0.60 for the "group interaction'. The rest of the factors fall between these tworange.

\section{B. Descriptive Analysis}

The respondent's opinion was obtained through Likert's five-point (1-5) scale, where scale 1 signifiesstrongly disagrees and scale 5 shows strongly agree. The rating 'very high' denotes score of 4.0 and above, 'average' denotes score below 4.0 up to 3.0, and 'poor' denotes score below 3.0.

\section{Group Interaction}

From the results in Table I, it can be seen that the mean on staff appraisals, staff meetings and management meet are about average (3.95, 3.94 and 3.15 respectively). Management interacts perceived as somewhat enriched (4.03). The standard deviation for the group intersection varied from 0.64 to 1.36 . This suggests more heterogeneous sampling of the management meet's score - the score are spread over a relatively larger range around the mean.

\begin{tabular}{|c|c|c|c|c|c|}
\hline & $N$ & Min & Max & Mean & $\begin{array}{c}\text { Standard } \\
\text { Deviation }\end{array}$ \\
\hline $\begin{array}{l}\text { We have regular } \\
\text { staff appraisals in } \\
\text { which we discuss } \\
\text { what employees } \\
\text { want }\end{array}$ & 66 & 2.00 & 5.00 & 3.9545 & .64287 \\
\hline $\begin{array}{l}\text { We have regular } \\
\text { staff meetings } \\
\text { with employees at } \\
\text { all levels attending }\end{array}$ & 66 & 2.00 & 5.00 & 3.9394 & .74710 \\
\hline $\begin{array}{l}\text { Management } \\
\text { meet with our } \\
\text { employees at least } \\
\text { once a year to find } \\
\text { out what } \\
\text { expectations they } \\
\text { have of their jobs } \\
\text { for the future }\end{array}$ & 66 & 1.00 & 5.00 & 3.1515 & 1.36147 \\
\hline $\begin{array}{l}\text { Management } \\
\text { interact directly } \\
\text { with our } \\
\text { employees to find } \\
\text { out how to make } \\
\text { them satisfied more } \\
\text { sal }\end{array}$ & 66 & 2.00 & 5.00 & 4.0303 & .85880 \\
\hline
\end{tabular}

\section{Wage Flexibility}

The wage flexibility in Table II rated 2 aspects as average and 1 aspect as very high. The average aspects are authority wages and regional salaries, 3.7273 and 3.9242 respectively. The adjust pay shown 4.0152 of mean. The standard deviation is varied from 0.71 to 0.83 .

TABLE II: WAGE FLEXIBILITY

\begin{tabular}{|l|c|c|c|c|c|}
\hline & $N$ & Min & Max & Mean & $\begin{array}{l}\text { Standard } \\
\text { Deviation }\end{array}$ \\
\hline $\begin{array}{l}\text { I have the authority to } \\
\text { adjust wages to } \\
\text { compensate for } \\
\text { regional differences }\end{array}$ & 66 & 2.00 & 5.00 & 3.7273 & .83289 \\
\hline $\begin{array}{l}\text { We adjust pay at the } \\
\text { local level according } \\
\text { to the local } \\
\text { competition for jobs }\end{array}$ & 66 & 2.00 & 5.00 & 4.0152 & .73364 \\
\hline $\begin{array}{l}\text { Regional salaries are } \\
\text { adjusted to reflect the } \\
\text { condition of the local } \\
\text { labor market }\end{array}$ & 66 & 2.00 & 5.00 & 3.9242 & .70842 \\
\hline
\end{tabular}




\section{E. Collegial Interaction}

The Table III mean result for collegial interaction indicates that all respondents are strongly agreed with the Internal Marketing activities. The standard deviations for collegial interaction are varied from 0.71 to 0.80 .

TABLE III: COLLEGIAL INTERACTION

\begin{tabular}{|l|l|l|l|l|l|}
\hline & $N$ & Min & Max & Mean & $\begin{array}{c}\text { Standard } \\
\text { Deviation }\end{array}$ \\
\hline $\begin{array}{l}\text { I try to find out my } \\
\text { employees real } \\
\text { feelings about their } \\
\text { jobs }\end{array}$ & 66 & 1.00 & 5.00 & 4.0909 & .79860 \\
\hline $\begin{array}{l}\text { If I notice one of my } \\
\text { employees is acting } \\
\text { differently to normal, }\end{array}$ & 66 & 2.00 & 5.00 & 4.2727 & .71351 \\
$\begin{array}{l}\text { I will try to find if } \\
\text { there is a problem } \\
\text { which is causing a } \\
\text { change in behavior }\end{array}$ & 66 & 2.00 & 5.00 & 4.1818 & .78268 \\
\hline $\begin{array}{l}\text { I regularly talk to my } \\
\text { staff to find out } \\
\text { about their work }\end{array}$ & 66 & 2.00 & 5.00 & 4.2727 & .73475 \\
\hline $\begin{array}{l}\text { I try to find out } \\
\text { what employees } \\
\text { want from the } \\
\text { company }\end{array}$ & 66 & & & \\
\hline
\end{tabular}

\section{F. Job Flexibility}

\begin{tabular}{|l|l|l|l|l|l|}
\hline \multicolumn{1}{|c|}{ TABLE IV: JOB FLEXIBILITY } & $\begin{array}{c}\text { Standard } \\
\text { Deviation }\end{array}$ \\
\hline $\begin{array}{l}\text { I allow my staff to } \\
\text { start late or leave } \\
\text { early to meet } \\
\text { outside }\end{array}$ & 66 & 1.00 & 5.00 & 2.7727 & 1.16084 \\
commitments & Min & Max & Mean & \\
\hline $\begin{array}{l}\text { If someone comes } \\
\text { me with a } \\
\text { personal problem, } \\
\text { I will always try to } \\
\text { accommodate } \\
\text { any changes in } \\
\text { their working } \\
\text { conditions that } \\
\text { they request }\end{array}$ & 66 & 1.00 & 5.00 & 3.0606 & 1.02099 \\
\hline $\begin{array}{l}\text { When we find that } \\
\text { employees would } \\
\text { like us to modify } \\
\text { their conditions of } \\
\text { employment, the } \\
\text { departments is } \\
\text { involved make } \\
\text { concerted efforts } \\
\text { to do so }\end{array}$ & 66 & 2.00 & 5.00 & 3.5152 & \\
\hline
\end{tabular}

Table IV shown the Job flexibility rated two aspects as average and one aspect as poor. The poor rate is about 2.7727 (allow) and average rate are 3.0606 and 3.5152 (accommodate and modify respectively). The standard deviation varied from 0.73 to 1.16 . This suggests more heterogeneous sampling of allow's score - the scores are spread over a relatively smaller range around the mean. On the other hand, there is a more heterogeneous sampling of accommodate's scores - the scores are spread over a relatively smaller range around the mean.

\section{G. External Environment}

TABLE V: EXTERNAL ENVIRONMENT

\begin{tabular}{|c|c|c|c|c|c|}
\hline & $N$ & Min & $\operatorname{Max}$ & Mean & $\begin{array}{c}\text { Standard } \\
\text { Deviation }\end{array}$ \\
\hline $\begin{array}{l}\text { Information } \\
\text { about firms } \\
\text { competing for the } \\
\text { same employees } \\
\text { as us is generated } \\
\text { independently by } \\
\text { several sources }\end{array}$ & 66 & 2.00 & 5.00 & 3.3788 & .67403 \\
\hline $\begin{array}{l}\text { We collect } \\
\text { information on } \\
\text { local employment } \\
\text { conditions by } \\
\text { informal means } \\
\text { (e.g. lunch with } \\
\text { local industry } \\
\text { friends, talks with } \\
\text { trade partners) }\end{array}$ & 66 & 1.00 & 5.00 & 3.4848 & 1.01136 \\
\hline $\begin{array}{l}\text { Several } \\
\text { departments get } \\
\text { together } \\
\text { periodically to } \\
\text { plan a response to } \\
\text { employment } \\
\text { changes taking } \\
\text { place in our local } \\
\text { business } \\
\text { environment }\end{array}$ & 66 & 2.00 & 5.00 & 4.0303 & .85880 \\
\hline
\end{tabular}

External environment in Table $\mathrm{V}$ rated 2 aspects $(3.3788$ for information and 3.4848 form collect information) as average and 1 aspect as very high. The standard deviations are varied from 0.67 to 1.01 . There is a more heterogeneous sampling of the collect information's scores - the scores are spread over a relatively smaller range around the mean $(s=1.01)$.

\section{H. Formal Interaction}

\begin{tabular}{|l|l|l|l|l|l|}
\hline \multicolumn{1}{|c|}{ TABLE VI: FORMAL INTERACTION } \\
\hline $\begin{array}{l}\text { We survey our staff } \\
\text { at least once a year } \\
\text { to get information } \\
\text { about their attitudes } \\
\text { to their work }\end{array}$ & 66 & 1.00 & 5.00 & 3.6364 & $\begin{array}{c}\text { Standard } \\
\text { Deviation }\end{array}$ \\
\hline $\begin{array}{l}\text { We often talk with } \\
\text { or survey people to } \\
\text { identify influences } \\
\text { on our employees' } \\
\text { behavior (e.g. } \\
\text { unions, sales } \\
\text { representatives, } \\
\text { customers) }\end{array}$ & 66 & 2.00 & 5.00 & 4.0909 & .75909 \\
\hline $\begin{array}{l}\text { We do a lot of } \\
\text { internal market } \\
\text { research }\end{array}$ & 66 & 2.00 & 5.00 & 4.1364 & .62969 \\
\hline
\end{tabular}


The mean results show in Table VI that the average score for survey at least once a year their staff to get information about their attitude to their work is lower (3.6364) than that of the often talk with or survey people to identify influenceson employees' behavior (4.0909) and do a lot of internal market research (4.1364). The standard deviation varied from 0.63 to 1.03.This also suggests that more heterogeneous sampling of the survey's score - the scores are spread over a relatively smaller range around the mean $(s=1.03)$.

\section{CONCLUSION}

The analysis leads to the following major findings and conclusion. From the results, it can be seen that the mean on staff appraisals, staff meetings and management meet are about average (3.95, 3.94 and 3.15 respectively). Management interacts perceived as somewhat enriched (4.03). The wage flexibility rated 2 aspects (authority wages and regional salaries) as average and 1 aspect (adjust pay) as very high. The mean result for collegial interaction indicates that all respondents are strongly agreed with the Internal Marketing activities. The Job flexibility rated two aspects as average (accommodate and modify) and one aspect as poor (allow). External environment rated 2 aspects (3.3788 for information and 3.4848 for collect information) as average and 1 aspect as very high (department). The mean results show that the average score for survey at least once a year their staff to get information about their attitude to their work is lower (3.6364) than that of the often talk with or survey people to identify influences on employees' behavior (4.0909) and do a lot of internal market research (4.1364).

\section{REFERENCES}

[1] M. Rafiq and P. Ahmed, "The Scope of internal marketing: defining the boundary between marketing and human resource management,' Journal of Marketing Management, vol. 9, no. 3, pp. 219-232, 1993.

[2] K. A. Pervais and M. Rafiq. (2003). Commentary: internal marketing issues and challenges. European Journal of Marketing. [Online]. 37(9). p. $1181 . \quad$ Available: http://www.emeraldinsight.com_Insight_ViewContentServlet_Filena me=_published_emeraldfulltextarticle_pdf_0070370901.pdf
[3] W. R. George, "Internal marketing and organizational behavior: A partnership in developing customer-conscious employees at every level," Journal of business Research, vol. 20, no. 1, pp. 63-70, 1990.

[4] G. Spiros, "Antecedents of internal marketing practice: some preliminary empirical evidence," International Journal of Service Industry Management, vol. 19, no. 3, 2008.

[5] L. L. Berry, "Services marketing is different," Business, pp. 24-30, May- June, 1980.

[6] B. Collins and A. Payne, "Internal marketing: A new perspective for HRM," European Management Journal, vol. 9, no. 3, pp. 261-270, 1991.

[7] J. Barnes, "The role of internal marketing; if the staff won't buy it, why should the customer?" Irish Marketing Review, vol. 49, no. 2, pp. 11-21, 1989.

[8] N. Piercy and N. Moran, "Internal marketing-the missing half of the marketing programme," Long Range Planning, 24, April, pp. 82- 93, 1991.

[9] L. L. Berry, "The employee as customer," Journal of Retail Banking, vol. 3, no. 1, pp. 33-40, 1991.

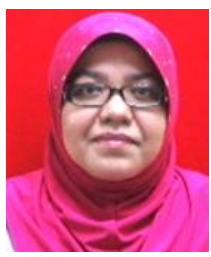

Zarina Abdul Munir is a senior lecturer at Universiti Teknologi Mara, Malaysia. Her area of interests include entrepreneurship, organizational behaviour and human resource development.

Akmal Aini Othmas is a lecturer at Universiti Teknologi Mara, Johor Branch, Malaysia. Her interest is in marketing and management.

Shamsul Azren Mohd Shukur is a senior lecturer at Universiti Teknologi Mara, Malaysia. His area of interests include in management change, human resource development and human resource management.

Rahimah Ithnin is working in Government Sector, Department of Special Affairs, Ministry of Communication and Multimedia Malaysia. Her area of interests include finance, management and marketing.

Syezreen Dalina Rusdi is a lecturer at Universiti Teknologi MARA, Malaysia. Her area of interests include human resource management and personel development. 